PROFESI (Profesional Islam)

Media Publikasi Penelitian; 2018; Volume 15; No 2.

Website: ejournal.stikespku.ac.id

\title{
Dampak Perceraian Orang Tua Terhadap Kesehatan Psikologis Remaja
}

\begin{abstract}
Kata Kunci:
Perceraian, Psikologis, Remaja
\end{abstract}

\author{
Ida Untari ${ }^{1^{*}}$, Kanissa Puspa Dhini Putri ${ }^{2}$, Muhammad Hafiduddin ${ }^{3}$ \\ ${ }^{1}$ Prodi DIII Keperawatan Stikes PKU Muhammadiyah Surakarta \\ ${ }^{2}$ Prodi DIII Keperawatan Stikes PKU Muhammadiyah Surakarta \\ ${ }^{3}$ Prodi DIII Keperawatan Stikes PKU Muhammadiyah Surakarta \\ *idauntari@stikespku.ac.id
} Keyword:
Divorce,
Psychological,
Adolescent

\begin{abstract}
Abstrak
Perceraian tidak hanya berdampak bagi yang bersangkutan (suami-isteri), namun juga melibatkan anak khususnya yang memasuki usia remaja, perceraian merupakan beban tersendiri bagi anak sehingga berdampak pada psikis. Reaksi anak terhadap perceraian orangtuanya, sangat dipengaruhi oleh cara orang tua berperilaku sebelum, selama dan sesudah perceraian. Tujuan penelitian ini untuk mengetahui dampak psikologis pada anak akibat perceraian orangtua. Metode penelitian menggunakan deskriptif kuantitatif, dengan pendekatan survey fenomenologis. Subyek penelitian ini adalah seluruh remaja yang orang tuanya telah bercerai dengan rentang waktu minimal 1 tahun setelah perceraian dengan purposive sampling sebanyak 30. Instrumen menggunakan kuesioner yang hasil data dianalisis secara univariat. Dampak yang terjadi meliputi anak ingin menang sendiri28 (93\%), sering tidak peka terhadap lingkungan 22 (73\%), mudah marah jika orang lain tidak sesuai dengan keinginan saya 19 (63\%), malu dengan perceraian orang tua 18 (60\%), sulit fokus terhadap sesuatu 15 (50\%), kehilangan rasa hormat dan mudah menyalahkan orang tua 15 (50\%), merasa tidak aman dengan lingkungan sekitar karena tidak ada orang tua yang melindungi secara utuh 15 (50\%), melakukan sesuatu yang salah 13 (43\%), tidak memiliki tujuan hidup 12 (40\%), tidak memiliki etika dalam bermasyarakat 11 (36\%, lebih mandiri 24 (80\%), terlatih dalam kegiatan keseharian 20 (66\%), cepat bangkit jika mengalami keterpurukan 12 (40\%), Dengan demikian anak remaja dengan perceraian orang tua menimbulkan dampak psikologis negative maupun positif. Dampak negatif lebih banyak timbul dibandingkan dengan dampak positif.
\end{abstract}

\section{Psychological Impacts on Teenagers Due to Parental Divorce}

\begin{abstract}
Divorce not only affects the concerned (husband and wife), but also involves children especially who entering the age of adolescence. Divorce is a burden for the child so st impact on the psychic. The child's reaction to his parents' divorce is greatly influenced by the way parents behave before, during and after the divorce. The purpose of this study is to determine the psychological impact on children due to parental divorce. The research method used quantitative descriptive, with phenomenological survey approach. Population in this study was all teenagers whose parents have divorced with a span of at least 1 year after divorce with purposive sampling of 30. Instruments using was questionnaires and univariate analysis. (63\%), irritability if others do not suit his/her wish 19 (63\%), embarrassed by parental divorce $18(60 \%)$, difficulty focusing on something $15(50 \%)$, loss of respect and easy to blame parent 15 (50\%), unsafe with the environment because no parent protecting intact 15 (50\%), doing something wrong 13 (36\%, more independent $24(80 \%)$, trained in daily activities 20 (66\%), fast rise if experienced 12 (40\% 40\%). Thus, adolescents with parental divorce have negative and positive psychological effects.More negative impacts arise than positive ones.
\end{abstract}




\section{PENDAHULUAN}

Data perceraian dari Kantor Pengadilan Agama kota Surakarta menunjukkan bahwa sejak tahun 2011 hingga 2016, banyaknya jumlah kasus perceraian terus bertambah, yaitu terdapat 864 kasus yang diputus pada 2011, sejumlah 922 kasus yang diputus pada tahun 2012, sejumlah 1.059 kasus yang diputus pada tahun 2013, angka kasus perceraian sempat menurun pada tahun 2014 sejumlah 1.014 kasus, dan 1.002 kasus yang diputus pada tahun 2015, sedangkan untuk tahun 2016 dari awal bulan januari sampai september sudah mencapai 886 kasus perceraian yang diputus, sedangkan kasus yang belum diputus terdapat 369 kasus dengan faktor penyebab tertinggi yaitu tidak adanya tanggung jawab, tidak ada keharmonisan, dan ekonomi.

Kepala Puslitbang Kehidupan Keagamaan Kemenag Muharam Marzuki mengatakan, angka perceraian di Indonesia lima tahun terakhir terus meningkat, dari dua juta pasangan menikah, sebanyak 15 hingga $20 \%$ bercerai. Sementara, jumlah kasus perceraian yang diputus Pengadilan Tinggi Agama seluruh Indonesia pada 2014 mencapai 382.231, naik sekitar 131.023 kasus dibanding tahun 2010 sebanyak 251.208 kasus. Sementara dalam persentase berdasarkan data Badan Peradilan Agama Mahkamah Agung, dalam lima tahun terakhir terjadi kasus Cerai Gugat mencapai 59\% hingga 80\% (Baiquni, 2016). Penyebabnya sendiri ada beberapa faktor yang mempengaruhi, diantaranya masalah ekonomi, tidak ada tanggung jawab, kekerasan dalam rumah tangga, campur tangan orang tua, perpindahan agama, juga orang ketiga. Permasalahan mengenai perceraian diperkuat dengan data semakin banyaknya perceraian yang terjadi di Indonesia dari tahun ke tahun.

Perceraian dapat diartikan sebagai berakhirnya suatu hubungan suami dan istri yang diputuskan oleh hukum atau agama (talak) karena sudah tidak ada saling ketertarikan, saling percaya dan juga sudah tidak ada kecocokan satu sama lain sehingga menyebabkan ketidakharmonisan dalam rumah tangga. Berdasarkan Data Badan Peradilan Agama Mahkamah Agung RI (2010), dari dua juta pasangan yang menikah tahun 2010, terdapat 285.184 pasangan bercerai. Kasus perceraian di Indonesia, termasuk angka tertinggi se-Asia Pasifik. Data tersebut, juga memperlihatkan bahwa $70 \%$ perceraian karena gugat cerai dari pihak istri dengan alasan tertinggi ketidakharmonisan (BKKBN).

Dalam penelitiannya Priyana (2011), mengatakan bahwa psikologi menunjukkan suatu perubahan kepribadian seseorang yang berkaitan dengan mental baik normal maupun abnormal dan mencakup beberapa aspek seperti: sikap, karakter, temperaman, rasionalitas, stabilitas emosional dan sosiabilitas. Secara psikologis anak yang kedua orang tuanya bercerai mengalami resiko terhadap tumbuh kembang jiwanya.

Perceraian tidak hanya berdampak bagi yang bersangkutan (suami-isteri), namun juga melibatkan anak khususnya yang memasuki usia remaja (Aminah, Andayani, dan Karyanta, 2014). Perceraian merupakan beban tersendiri bagi anak sehingga berdampak pada psikis. Seperti perasaan malu, sensitif, dan rendah diri hingga menarik diri dari lingkungan. Hal-hal yang biasanya ditemukan pada anak ketika orangtuanya bercerai adalah rasa tidak aman, tidak diinginkan atau ditolak oleh orangtuanya yang pergi, sedih dan kesepian, marah, kehilangan, merasa bersalah, menyalahkan diri sendiri sebagai penyebab orang tua bercerai.

Berdasarkan penelitian yang pernah dilakukan oleh Aminah, Andayani, dan Karyanta (2014) dampak psikologis terbagi menjadi dampak kognisi, dampak emosi dan dampak konasi/psikomotor yang kesemuanya mempengaruhi penyesuaian diri subjek yang berimbas pada dunia sosial. Anak yang belum siap menghadapi rasa kehilangan akan terpukul, dan kemungkinan besar mengalami perubahan tingkah laku seperti menjadi pemarah, pembangkang, suka melamun, mudah tersinggung, suka menyendiri, dan sebagainya. Jika ini terjadi, anak bisa kehilangan kontrol, dan tidak mampu lagi berpikir sehat.

Bagaimana anak bereaksi terhadap perceraian orangtuanya, sangat dipengaruhi oleh cara orang tua berperilaku sebelum, selama dan sesudah perceraian. Anak akan membutuhkan dukungan, kepekaan, dan kasih sayang yang lebih besar untuk membantunya mengatasi kehilangan yang dialami selama masa sulit setelah orang tuanya bercerai (Ningrum, 2013).

Remaja adalah masa transisi dari masa anakanak ke dewasa yang mencakup aspek biologi, kognitif dan perubahan sosial yang berlangsung antara 10-19 tahun dan belum kawin. Batasan 
PROFESI (Profesional Islam)

Media Publikasi Penelitian; 2018; Volume 15; No 2.

Website: ejournal.stikespku.ac.id

usia remaja menurut WHO adalah 12 sampai 24 tahun. Monks mengatakan bahwa masa remaja dapat dibagi menjadi tiga kelompok usia, yaitu: (1). Remaja awal (usia 12-15 tahun). (2) Remaja pertengahan (usia 15-18 tahun). (3) Remaja akhir, berkisar pada (usia 18-21 tahun). Pada masa ini individu mulai merasa stabil. Mulai mengenal dirinya, mulai memahami arah hidup, dan menyadari tujuan hidupnya (Ningrum, 2013). Remaja merupakan fase yang penting bagi individu untuk pembentukan keperibadiannya. Ketika orang-tua dan anak memiliki hubungan yang positif dan adaptif maka akan membantu remaja dalam pencapaian tugas perkembangan yang optimal. Sebaliknya hubungan yang tidak harmonis antara anak dengan orangtua dapat berpengaruh negtif bagi kehidupan remaja. Salah satu bentuk hubungan yang negatif dapat berasal dari perceraian yang terjadi dalam sebuah keluarga (Hurlock, 2012).

Beberapa remaja yang orangtua bercerai dan belum dapat menerima perceraian orangtuanya akan memiliki keinginan yang sangat besar untuk mewujudkan keluarga menjadi normal kembali dengan membujuk agar kedua orangtuanya rujuk. Pada sebagian remaja mungkin ada yang melakukan cara-cara yang mengarah pada tindakan merugikan diri sendiri karena merasa gagal menyatukan kedua orangtuanya kembali. Adanya berbagai reaksi pada remaja terhadap perceraian orangtua berkaitan erat dengan penerimaan individu terhadap perceraian (Aminah, Andayani \& Karyanta, 2014).

Berdasarkan data yang didapat dari BPS semester II tahun 2016 terdapat 10.330 kasus secara keseluruhan di Kota Surakarta. Di Kelurahan Kepatihan Wetan, Kecamatan Jebres terdapat 53 kasus perceraian. Kasus perceraian tersebut sangat memprihatinkan karena dapat berdampak pada psikologis anak terutama pada usia remaja, berdasarkan observasi yang dilakukan pada 3 orang remaja yang orang tuanya bercerai menuturkan bahwa pada awalnya mereka merasa takut, malu dan tidak ingin orang tuanya bercerai, salah satu dari remaja tersebut ada yang mengatakan bahwa setelah orang tuanya bercerai tidak pernah berhubungan lagi karena dilarang oleh sang ibu. Tujuan dari penelitian adalah untuk mengetahui dampak psikologis pada anak akibat perceraian orangtua.

\section{METODE PENELITIAN}

Metode yang digunakan dalam penelitian adalah deskriptif kuantitatif, dengan pendekatan survey fenomenologis. Subyek dalam penelitian ini seluruh remaja yang orang tuanya telah bercerai dalam kurun waktu 1 tahun setelah perceraian. Lokasi penelitian di Kelurahan Kepatihan Wetan RW I dan II Jebres Surakarta yang dilaksnakan pada bulan April 2017. Teknik sampel penelitian dengan purposive sampling berupa kriteria inklusi remaja yang berusia $15-21$ tahun, berada di lokasi penelitian dan bersedia menjadi responden. Jumlah responden sebanyak 30 orang. Instrumen yang digunakan menggunakan kuesioner yang terdiri dari pertanyaan untuk menanyakan dampak positif sejumlah 3 pertanyaan dan 10 untuk dampak negative dengan pilihan jawabann ya dan tidak sekaligus dilakukan analisa univariat. Dalam penelitian ini, dalam keikutsediaan menjadi responden menuliskan inform consent.

\section{HASIL DAN PEMBAHASAN}

Hasil penelitian, diperoleh banyak dari karakteristik responden. Berikut karakteristik dari responden berdasarkan jenis kelamin didapatkan data sebagai berikut:

Tabel 1. Distribusi Frekuensi Responden berdasarkan Jenis Kelamin.

\begin{tabular}{ccc}
\hline $\begin{array}{c}\text { Jenis } \\
\text { Kelamin }\end{array}$ & Frekuensi & Persentase (\%) \\
\hline Laki-laki & 13 & 43.3 \\
Perempuan & 17 & 56.7 \\
\hline Total & 30 & 100.0 \\
\hline
\end{tabular}

Berdasarkan tabel 1 dapat dijelaskan mayoritas responden adalah perempuan sebanyak 17 orang $(54.8 \%)$.

Karakteristik responden berdasarkan umur didapatkan data sebagai berikut:

Tabel 2. Distribusi Frekuensi Responden Berdasarkan Umur

\begin{tabular}{ccc}
\hline $\begin{array}{c}\text { Umur } \\
\text { (Tahun) }\end{array}$ & Frekuensi & Persentase (\%) \\
\hline $12-15$ & 8 & 26.6 \\
$15-18$ & 12 & 40 \\
$19-21$ & 10 & 33.4 \\
\hline Total & 30 & 100.0 \\
\hline
\end{tabular}


PROFESI (Profesional Islam)

Media Publikasi Penelitian; 2018; Volume 15; No 2.

Website: ejournal.stikespku.ac.id

Berdasarkan tabel 2 distribusi frekuensi berdasarkan umur, mayoritas berumur 16-18 tahun sebanyak 12 orang (38.7\%) disusul usia 19 -21 tahun sejumlah $10(33,4 \%)$ dan usia $12-15$ tahun sejumlah $8(26,6 \%)$.

Karakteristik responden berdasarkan tingkat pendidikan didapatkan data sebagai berikut:

Tabel 3. Distribusi Frekuensi Responden berdasarkan Tingkat Pendidikan

\begin{tabular}{ccc}
\hline $\begin{array}{c}\text { Tingkat } \\
\text { Pendidikan }\end{array}$ & Frekuensi & Persentase (\%) \\
\hline SD & 1 & 3.3 \\
SMP & 9 & 30 \\
SMA & 16 & 53.5 \\
D3 & 2 & 6.6 \\
Sarjana & 2 & 6.6 \\
\hline Total & 30 & 100.0 \\
\hline
\end{tabular}

Berdasarkan tabel 3 distribusi frekuensi berdasarkan tingkat pendidikan. mayoritas berpendidkan SMA sebanyak 16 orang $(51.6 \%)$, dilanjutkan dengan tingkat pendidikan SMP 9 (30\%), perguruan tinggi (D3 dan Sarjana) sebesar $4(13,2 \%)$ dan pendidikan SD sebanayk $1(3,3 \%)$.

Karakteristik responden berdasarkan lama perceraian didapatkan data sebagai berikut:

Tabel 4. Distribusi Frekuensi Responden berdasarkan Lama Perceraian

\begin{tabular}{ccc}
\hline $\begin{array}{c}\text { Lama Perceraian } \\
\text { (Tahun) }\end{array}$ & Frekuensi & $\begin{array}{c}\text { Persentase } \\
(\%)\end{array}$ \\
\hline 1 & 8 & 26.8 \\
2 & 11 & 36.6 \\
3 & 11 & 36.6 \\
\hline Total & 30 & 100.0 \\
\hline
\end{tabular}

Berdasarkan tabel 4. distribusi frekuensi berdasarkan lama perceraian, mayoritas lama perceraian yaitu dua dan tiga tahun terdapat 11 orang $(35.5 \%)$.

Karakteristik responden berdasarkan tempat tinggal didapatkan data sebagai berikut:

Tabel 5. Distribusi Frekuensi Responden Berdasarkan Tempat Tinggal.

\begin{tabular}{lcc}
\hline $\begin{array}{c}\text { Tempat Tinggal } \\
\text { Saat Ini }\end{array}$ & Frekuensi & $\begin{array}{c}\text { Persentase } \\
(\%)\end{array}$ \\
\hline Salah satu orang & 19 & 63.3 \\
tua & & 20 \\
Kakek-nenek & 6 & 16.7 \\
Saudara & 5 & 0 \\
Orang lain & 0 & 100.0 \\
\hline Total & 30 & \\
\hline
\end{tabular}

Berdasarkan tabel 5, tempat tinggal saat ini. mayoritas tinggal dengan salah satu orangtua, terdapat 19 orang $(61.3 \%)$, dilanjutkan ikut Kakek nenek $6(20 \%)$, ikut dengan saudara 5 $(16,7 \%)$.

Karakteristik responden berdasarkan dampak psikologis didapatkan data sebagai berikut:

Tabel 6. Dampak Kesehatan Psikologis

\begin{tabular}{|c|c|c|c|c|c|c|c|}
\hline No. & Pertanyaan & $\mathbf{Y a}$ & $\begin{array}{l}\text { Persentase } \\
\quad(\%)\end{array}$ & Tidak & $\begin{array}{l}\text { Persentase } \\
\quad(\%)\end{array}$ & Total & $\begin{array}{l}\text { Persentase } \\
\quad(\%)\end{array}$ \\
\hline 1. & Menjadi lebih mandiri. & 24 & 80 & 6 & 20 & 30 & 100 \\
\hline 2. & $\begin{array}{l}\text { Menjadi terlatih dalam kegiatan } \\
\text { keseharian. }\end{array}$ & 20 & 66 & 10 & 34 & 30 & 100 \\
\hline 3. & $\begin{array}{l}\text { Menjadi cepat bangkit jika mengalami } \\
\text { keterpurukan. }\end{array}$ & 12 & 40 & 18 & 60 & 30 & 100 \\
\hline 4. & $\begin{array}{l}\text { Merasa malu dengan perceraian orang } \\
\text { tua. }\end{array}$ & 18 & 60 & 12 & 40 & 30 & 100 \\
\hline
\end{tabular}


PROFESI (Profesional Islam)

Media Publikasi Penelitian; 2018; Volume 15; No 2.

Website: ejournal.stikespku.ac.id

\begin{tabular}{|c|c|c|c|c|c|c|c|}
\hline No. & Pertanyaan & Ya & $\begin{array}{c}\text { Persentase } \\
(\%)\end{array}$ & Tidak & $\begin{array}{c}\text { Persentase } \\
(\%)\end{array}$ & Total & $\begin{array}{c}\text { Persentase } \\
(\%)\end{array}$ \\
\hline 5. & $\begin{array}{l}\text { Merasa mudah marah jika orang lain } \\
\text { tidak sesuai dengan keinginan saya. }\end{array}$ & 19 & 63 & 11 & 37 & 30 & 100 \\
\hline 6. & Merasa sulit fokus terhadap sesuatu. & 15 & 50 & 15 & 50 & 30 & 100 \\
\hline 7. & $\begin{array}{l}\text { Merasa kehilangan rasa hormat } \\
\text { terhadap orang tua dan mudah } \\
\text { menyalahkan orang tua. }\end{array}$ & 15 & 50 & 15 & 50 & 30 & 100 \\
\hline 8. & Melakukan sesuatu yang salah. & 13 & 43 & 17 & 57 & 30 & 100 \\
\hline 9. & Sering tidak peka terhadap lingkungan. & 22 & 73 & 8 & 27 & 30 & 100 \\
\hline 10. & $\begin{array}{l}\text { Tidak memiliki etika dalam } \\
\text { bermasyarakat. }\end{array}$ & 11 & 36 & 20 & 64 & 30 & 100 \\
\hline 11. & Tidak memiliki tujuan hidup. & 12 & 40 & 18 & 60 & 30 & 100 \\
\hline 12. & Ingin menang sendiri. & 28 & 93 & 2 & 6.7 & 30 & 100 \\
\hline 13. & $\begin{array}{l}\text { Merasa tidak aman dengan lingkungan } \\
\text { sekitar karena tidak ada orang tua yang } \\
\text { melindungi secara utuh. }\end{array}$ & 15 & 50 & 15 & 50 & 30 & 100 \\
\hline
\end{tabular}

Berdasarkan tabel 6, mayoritas jawaban yang adalah Ya pada pertanyaan nomor 12 sebanyak $28(93 \%)$ dan jawaban Tidak pada pertanyaan nomor 10 sebanyak 20 (64\%).

\subsection{Umur Responden}

Pada penjelasan terkait umur, distribusi frekuensi diketahui bahwa ada 9 orang (29\%) yang memiliki rentang umur 12-15 tahun, 12 orang $(38.7 \%)$ yang memiliki rentang umur 15 18 tahun dan ada 10 orang (32.3\%) yang berumur 18-21 tahun. Faktor-faktor yang mempengaruhi dampak psikologis perceraian adalah umur individu yang terhitung mulai saat dilahirkan sampai saat ini. Remaja adalah kata yang mengandung berbagai kesan dan konotasi tergantung darimana dan siapa yang memandangnya (Surbakti, 2009). Hall menyebutkan bahwa masa remaja sebagi periode yang berada dalam dua situasi antara goncangan, penderitaan, asmara, pemberontakan dengan otoritas orang dewasa. Dengan ciri-ciri sering dan mulai timbul sikap menantang dan melawan terutama kepada orang terdekat seperti orang tua, guru, dan sebagainya (Yusuf, 2010).
Remaja memiliki beberapa tahapan untuk dewasa. Remaja awal, berada pada rentang usia 12 sampai 15 tahun, merupakan masa negatif. Remaja pertengahan, dengan rentang usia 15 sampai 18 tahun. Pada masa ini individu menginginkan sesuatu dan mencari-cari sesuatu. Monks mengatakan pada masa remaja ini memikirkan konsep diri dan konsep dirinya relatif stabil. Namun kenyataannya berbeda dengan yang ditemukan dilapangan, hasil dari penelitian pada remaja pertengahan yang orang tuanya bercerai adalah, remaja cenderung ingin menang sendiri dan mudah marah jika orang lain tidak sesuai dengan keinginannya seperti berperilaku kasar. Beberapa dari remaja tersebut juga kehilangan rasa hormat terhadap orang tuanya dengan menunjukan kemarahan dan menyalahkan perceraian orang tuanya. Remaja akhir, berkisar pada usia 18 sampai 21 tahun. Pada masa ini individu mulai merasa stabil. Mulai mengenal dirinya, mulai memahami arah hidup, dan menyadari tujuan hidupnya. Remaja pada tahap akhir ini juga menjadi lebih mandiri dalam hal finansial dan bersosialisasi, tidak mengisolasi diri lagi dan lebih terbuka dengan lingkungan sekitar. 


\subsection{Tingkat Pendidikan}

Pada tingkat pendidika, diketahui bahwa ada 1 orang $(3.3 \%)$ yang memiliki tingkat pendidikan SD, ada 9 orang (30\%) yang memiliki tingkat pendidikan SMP, ada 16 orang (53.5\%) yang memiliki tingkat pendidikan SMA, ada 2 orang $(6.6 \%)$ yang memiliki tingkat pendidikan D3 2 orang $(6.6 \%)$ dan 2 orang (6.6\%) yang memiliki tingkat pendidikan sarjana. Faktor-faktor yang mempengaruhi psikis adalah pendidikan. Pendidikan dapat mempengaruhi seseorang termasuk juga perilaku seseorang akan pola fikir terutama dalam memotivasi untuk berperan, makin tinggi pendidikan seseorang makin mudah menerima informasi dan keadaan.Kita sering kali memecahkan suatu masalah berdasarkan proses pemikiran yang logis. Pemikiran ini merupakan komponen penting dalam pendekatan ilmiah, tetapi alasan rasional yang terbatas, dari mana seseorang memulai tergantung dari mana informasi tersebut didapatkan dan alasan tersebut tidak efisien untuk mengevaluasi akurasi permasalahan.

\subsection{Lama Perceraian}

Pada data lama perceraian didapatkan lama perceraian semua lebih dari satu tahun tahun. Remaja yang orang tuanya bercerai akan membutuhkan waktu yang cukup lama untuk menerima keadaan tersebut. Ningrum (2013) mengatakan bahwa rentang waktu perceraian yang dilakukan oleh orang tua dianggap mampu mempengaruhi penyesuain diri anak. Berdasarkan temuan yang ada dilapangan remaja yang orang tuanya bercerai dalam kurun waktu satu tahun cenderung melakukan hal-hal yang negatif dan depresi, awalnya remaja merasa tidak aman (insecure) karena ada salah satu orangtua yang tidak lagi tinggal bersamanya, lalu muncul perasaan sedih, kesepian, terkadang malu dengan perceraian orang tuanya sehingga mengisolasi diri (Hurlock, 2012).

Pada masa ini remaja lebih percaya kepada teman-temannya daripada orang tua yang dianggap bermasalah. Jika remaja lebih percaya terhadap temannya dan terjerumus kedalam pergaulan bebas maka tidak menutup kemungkinan nilai-nilai keagamaan dan akademik merosot, tingkah laku seksual terlampau dini, mengkonsumsi minuman keras, dan melakukan tindakan kekerasan. Perilaku remaja sangat rentan terhadap lingkungan, masalah remaja yang paling sulit adalah penyesuaian terhadap lingkungan sosial. Untuk mencapai pola sosialisasi dewasa, remaja harus membuat banyak penyesuaian baru. Remaja harus mempertimbangkan pengaruh kelompok sebaya, perubahan dalam perilaku sosial, pembentukan kelompok sosial baru dan nilainilai baru dalam memilih teman (Sumiati, Dinarti, Nurhaeni, dan Aryani, 2009).

Dari hasil temuan di lapangan, lama perceraian orang tua juga mempengaruhi proses penerimaan remaja, seperti kebanyakan responden yang menjadi lebih mandiri setelah melalui tahun pertama perceraian orang tua mereka. Pada tahun kedua setelah perceraian orang tuanya, remaja mulai dapat menerima perceraian tersebut dan mulai mengalami perubahan, remaja mulai mencari cara untuk bertahan disituasi yang menurutnya sulit, dan menjadi lebih mandiri dalam hal-hal tertentu, hal tersebut dapat dilihat dari hasil survey kuesioner diatas. Namun ada sebagian remaja masih mengalami dampak negatif yang berkepanjangan juga merasa terpuruk karena tidak adanya dukungan sosial maupun lingkungan yang memberikan dampak positif. Pada tahun ketiga sebagian remaja mulai memahami dan menerima keputusan orang tua mereka sehingga membuat remaja menjadi lebih mandiri dan matang dalam berpikir dan dapat menyikapi persoalan secara dewasa.

\subsection{Tempat Tinggal Saat Ini}

Tempat tinggal responden, mayoritas hidup dengan salah satu orangtua, terdapat 19 orang $(61.3 \%)$, lainnya tinggal dengan kakeknenek dan saudara. Sheridan dan Radmacher mengatakan dukungan sosial adalah kehadiran orang lain yang dapat membuat individu percaya bahwa dirinya dicintai, diperhatikan dan merupakan bagian dari kelompok sosial, yaitu keluarga, rekan kerja dan teman dekat (Wikipedia). Dalam hal ini dukungan sosial yang dibutuhkan remaja adalah orang tua. Pengasuhan yang dilakukan oleh orang tua bergantung pada cara interaksi antara keduanya (orang tua-anak). Rohner mengatakan faktor yang memengaruhi hubungan orang tua dan 
PROFESI (Profesional Islam)

Media Publikasi Penelitian; 2018; Volume 15; No 2.

Website: ejournal.stikespku.ac.id

anak adalah pengasuhan yang dipenuhi kasih sayang dan kehangatan. Hasil penelitian Lila, Garcia, dan Gracia menunjukkan bahwa pengasuhan orang tua yang dipenuhi kehangatan dan kasih sayang berhubungan positif dengan perkembangan anak. Eunjung menambahkan, pada keluarga yang mengalami perceraian dan memiliki tekanan yang mengakibatkan depresi dan stres baik ayah maupun ibu berpengaruh positif tehadap perilaku pengasuhan penolakan (agresi), pengabaian, dan perasaan tidak sayang (Asilah dan Hastuti, 2014).

Sebagian remaja yang di asuh dan tinggal dengan salah satu orang tuanya mengalami beberapa peristiwa yang kurang menyenangkan, hal ini membuat remaja menjadi murung dan tidak mampu menerima kenyataan bahwa orang tuanya telah bercerai, remaja juga kurang percaya diri ketika mengemukakan pendapat juga merasa malu dengan keadaanya, hal ini mengakibatkan remaja sulit bergaul dengan orang lain, ketidakmampuan remaja dalam mengendalikan emosi ketika melampiasakan amarah membuat remaja sulit dalam menyesuaikan diri dengan keadaan disekitarnya.

Hasil penelitian Asilah dan Hastuti (2014) menunjukkan bahwa sebanyak 98 persen remaja memperoleh pengasuhan afeksi dan dua persen pengabaian dari ibunya. Sun mengungkapkan dalam penelitiannya bahwa, perceraian dapat berdampak positif jika perceraian tersebut dapat menyelesaikan konflik yang terjadi pada orang tua sehingga anak terhindar dari suasana keluarga yang penuh ketegangan (Dewi dan Utami, 2015).

\subsection{Dampak Psikologis Perceraian Orang Tua}

Responden yang memberikan jawaban Ya dengan terbanyak yaitu pada pertanyaan nomor 12 dengan persentase $93 \%$ dengan pertanyaan tentang rasa ingin menang sendiri dan jawaban Tidak pada pertanyaan nomor 10 dengan sebesar $64 \%$ berupa pertanyaan tidak memiliki etika dalam bermasyarakat.

Dampak positif yang muncul berupa menjadi lebih mandiri $80 \%$ responden menjadi lebih mandiri. Hal ini anak tidak tergantung dari orang tua karena mereka dituntut untuk bisa berbuat tanpa pendampingan dari orang tua. Dampak menjadi terlatih juga muncul pada responden sebesar $66 \%$ dimana pada observasi remaja dalam melakukan sesuatu salah satu contoh berupa mengerjakan pekerjaan rumah menjadi terlatih. Dampak menjadi cepat bangkit jika mengalami keterpurukan, responden lebih banyak mengalami hal tersebut sebesar $60 \%$.

Dampak negative yang muncul meliputi merasa malu dengan perceraian orang tua, Merasa mudah marah jika orang lain tidak sesuai dengan keinginan saya, Merasa sulit fokus terhadap sesuatu, merasa kehilangan rasa hormat terhadap orang tua dan mudah menyalahkan orang tua, melakukan sesuatu yang salah, sering tidak peka terhadap lingkungan, tidak memiliki etika dalam bermasyarakat, tidak memiliki tujuan hidup, ingin menang sendiri, merasa tidak aman dengan lingkungan sekitar karena tidak ada orang tua yang melindungi secara utuh. Dampak negatif mendapatkan angka yang bervariasi sehingga hal ini menunjukkan, perceraian dipastikan memunculkan dampak prikologis negatif pada anak.

\section{SIMPULAN}

Simpulan dalam penelitian ini adalah dampak perceraian orang tua menimbulkan dampak psikologis negatif maupun positif. Dampak negatif lebih banyak timbul seperti malu dengan perceraian orang tua, mudah marah jika orang lain tidak sesuai dengan keinginan saya, sulit fokus terhadap sesuatu, kehilangan rasa hormat terhadap orang tua dan mudah menyalahkan orang tua, melakukan sesuatu yang salah, sering tidak peka terhadap lingkungan, tidak memiliki etika dalam bermasyarakat, tidak memiliki tujuan hidup, ingin menang sendiri, merasa tidak aman dengan lingkungan sekitar karena tidak ada orang tua yang melindungi secara utuh dan semua data bervaraisi dibandingkan dengan dampak positif berupa menjadi lebih mandiri, terlatih dalam kegiatan keseharian, cepat bangkit jika mengalami keterpurukan.

\section{REFERENSI}

Aminah, Andayani, \& Karyanta. 2014. Proses Penerimaan Anak (Remaja Akhir) Terhadap Perceraian Orangtua Dan Konsekuensi Psikososial Yang Menyertainya. Jurnal. Fakultas Kedokteran Program Studi Psikologi Universitas Sebelas Maret. 
eJurnal Psikologi Jppsikologiabnormaldd 120003. Diunduh pada 12 Oktober $2016,<$ http://www.ejurnal. com/2014/12/Proses-Penerimaan-AnakRemaja-Akhir. html $>$

Arikunto, S. 2010. Prosedur Penelitian Suatu Pendekatan Pendekatan Praktik. Jakarta: Rineka Cipta

Asilah \& Hastuti, Dwi. 2014. Hubungan Tingkat Stres Ibu Dan Pengasuhan PenerimaanPenolakan Dengan Konsep Diri Remaja Pada Keluarga Bercerai. Jurnal. Fakultas Ekologi Manusia Institut Pertanian Bogor. Jur. Ilm. Kel. \& Kons., Januari 2014, p : 10-18 Vol. 7, No. 1 ISSN : 1907 - 6037. Diunduh pada 1 Mei 2017, $<$ https://scholar.google.com/scholar?q $=\mathrm{HU}$ BUNGAN+TINGKAT+STRES+IBU+DA N+PENGASUHAN+PENERIMAANPENOLAKAN+DENGAN+KONSEP+DIR I+REMAJA+PADA+KELUARGA+BERC ERAI\&btnG $=\& \mathrm{hl}=\mathrm{id} \&$ as $\mathrm{sdt}=0 \% 2 \mathrm{C} 5 \& \mathrm{as}$ ylo $=2013 \&$ as_vis $=1>$

Badan Pusat Statistik Catatan Sipil Kota Surakarta. 2016. Laporan Jumlah Perceraian Semester 1 Tahun 2016

Baiquni, A. "Angka Perceraian di Indonesia Meningkat 80 Persen". Diakses pada 18 Oktober 2016 , $<$ http://www.dream.co.id/news/angkaperceraian-meningkat-lima-tahun-terakhir1601200.html>

BKKBN. "Angka Perceraian Di Indonesia Tertinggi Di Asia Pasifik". Diakses (online) pada 10 Oktober 2016, <http://www. bkkbn.go.id/>

Corey, Gerald. 2010. Teori Dan Praktek Konseling \& Psikoterapi. Bandung: Refika Aditama
Dewi, P.S \& Utami, M.S. 2015. Subjective Well-Being Anak Dari Orang Tua Yang Bercerai. Jurnal. Fakultas Psikologi Universitas Gadjah Mada. Vol. 35, NO. 2, 194 - 212 ISSN: 0215-8884. Diunduh pada 1 Mei 2017,

Hurlock, E. B. 2012. Psikologi Perkembangan. Jakarta: Erlangga

Ningrum, P.Rosalia. 2013. Perceraian Orang Tua Dan Penyesuaian Diri Remaja. eJournal Psikologi, 2013, 1 (1): 69-79 ISSN 0000-0000, ejournal.psikologi.fisipunmul.org. Diunduh pada 12 Oktober 2016, http://www.e-jurnal.com/

2014/12/perceraian-orang-tua-danpenyesuaian. html

Pengadilan Negri Agama Kota Surakarta. 2016. Laporan Perkara Yang Diterima Dan Diputus Pada Pengadilan Negri Agama Kota Surakarta Tahun 2011-2016

Priyana, D. 2011. Dampak Perceraian Terhadap Kondisi Psikologis Dan Ekonomis Anak (Studi Kasus Pada Keluarga Yang Bercerai Di Desa Logede Kecamatan Sumber Kabupaten Rembang). Skripsi. Jakarta: Fakultas Ilmu Sosial Universitas Negeri Semarang

Republik Indonesia. 1974. Undang-Undang Republik Indonesia Nomor 1 Tahun 1974 Tentang Perkawinan Pasa 38. Diakses pada 05 Desember 2016, <http://renyalda.blog spot.co.id/2009/04/2.html >

Sugiyono. 2014. Metode Penelitian Kualitatif, Kuantitatif Dan $R \& B$. Bandung: Alfabeta

Surbakti, M.A. 2009. Kenalilah Anak Remaja Anda. Jakarta: PT Elex Media Komputindo

Yusuf, S. 2010.Psikologi Perkembangan Anak \& Remaja. Bandung: PT Remaja Rosdakarya 